\title{
On-The-Job-Training (OJT) of KSU Students at the Agro studies International Centre for Agricultural Studies in Israel: An Assessment
}

\author{
Esmerlyn P. Bayangan, Paulino P. Reyes II, Joy Grace P. Doctor
}

Kalinga State University, Philippines

Received: 05 Nov 2020; Received in revised form: 17 Dec 2020; Accepted: 21 Dec 2020; Available online: 31 Dec 2020

(C)2020 The Author(s). Published by Infogain Publication. This is an open access article under the CC BY license

(https://creativecommons.org/licenses/by/4.0/).

\begin{abstract}
This study focused on the On-The-Job-Training(OJT) of KSU Students at the AgroStudies International Centre for Agricultural Studies in Israel. The study aimed to determine the level of attainment of the objectives of the On-The-Job-Training program in partnership with Agro-studies as well as the factors affecting the level of attainment of these objectives. Problems encountered by the student interns during the OJT in Israel were identified too. The structured questionnaires were used for data gathering. The respondents were students from the Kalinga State University at the same time alumni of Israel AgroStudies.

The findings showed that there were more males than females and the Bachelor of Science in Agriculture had the greatest number compared to other Agriculture related programs. It was found out that the objectives of the On-The-Job-Training program in partnership with Agro-studies was much attained. Moreover, the factors cited moderately affected the attainment of these objectives. There were problems encountered by the interns during their internship but were dealt with.
\end{abstract}

Keywords-Agricultural Studies, Assessment, On-The-Job-Training.

\section{INTRODUCTION}

It is the policy of KSU to provide quality tertiary education to its students by providing alternative opportunities to strengthen the knowledge acquired in the classroom through OJTA or SIAP. However, it is voluntary on the part of the students notwithstanding that the curriculum requires international practicum. (Revised KSU OJTA/SIAP Manual, 2015)

On-The-Job-Training Program of the College of Agriculture aims of practical training to help students develop important skills and abilities that support professional studies and prepare them for work later on.OJT show students the reality about working as Confucius once said:" If all I do is hear, I will forget. If I hear and see, I will remember. If I hear, see and do, I will understand."
The Kalinga State University is among the state universities in the Philippines who are participating in the OnThe-Job-Training in agriculture in collaboration with Israel Agro-Studies which started in the School year 2009-2010.

Israel Agro-studies internship program is an organization that provides a unique apprenticeship in agriculture, combining advanced studies and hands on "learning by doing" in various agricultural areas to students from different countries. The program is to enhance student's theoretical education and practical skills, on actual agricultural production system and expose students to modern ways of farming. The program is an 11 month paid apprenticeship

Agro-studies collaborates with dozens of carefully selected farms across Israel, to ensure each student is nurtured in the most enabling and stimulating learning environment, 
allowing them to benefit from real exposure to the most advanced agricultural working methods. The needed basic training and job skills also provide them the opportunities to improve technical agricultural work and not to mention the high senses of self-teem and self-respect from the work experiences that they encounter (www.agrostudies.com).

The KSU participated in two (2) major categories offered by Israel AgroStudies program, crop science and animal science. Crop science majors were assigned in horticulture such as plantation crops, nursery, packaging and many others. Animal science was assigned to livestock such as poultry production and maintenance and dairy farm.

Classes were also taught once a week on three campuses, one in Tel-Hai College in the North, another at the Rupin College and third at Kfar-Silver. In addition, each group is assigned a tutor who accompanies the group of student OJT in their internship based on their area of study.

This assessment shall serve as basis for improving the management of the On-The-Job-Training program of the Kalinga State University to maximize the benefits of the said program in collaboration with "Agro-studies" The International Centre for Agricultural Studies in Israel.

Specifically (1) to determine the level of attainment of the objectives of the On-The-Job-Training program in partnership with Agro-studies; (2)to determine extent of factors affecting the level of attainment of these objectives; and (3) to identify the problems encountered by students during their OJT in Israel.

Table 1. Presents the percentage distribution of OJTs in Terms of Gender

\begin{tabular}{|l|l|l|l|l|l|l|}
\hline \multirow{2}{*}{ YEAR } & \multicolumn{3}{|l|}{ MALE } & FEMALE & \multicolumn{2}{l|}{ TOTAL } \\
\cline { 2 - 7 } & F & $\%$ & FEMALE & $\%$ & F & $\%$ \\
\hline $2009-2010$ & 6 & 3.82 & 0 & 0 & 6 & 3.82 \\
\hline $2010-2011$ & 12 & 7.64 & 0 & 0 & 12 & 7.64 \\
\hline $2011-2012$ & 16 & 10.19 & 0 & 0 & 16 & 10.19 \\
\hline $2012-2013$ & 15 & 9.55 & 0 & 0 & 15 & 9.55 \\
\hline $2013-2014$ & 28 & 17.83 & 3 & 9.09 & 31 & 16.32 \\
\hline $2014-2015$ & 43 & 27.39 & 22 & 66.67 & 65 & 34.21 \\
\hline $2015-2016$ & 20 & 12.73 & 4 & 12.12 & 24 & 12.63 \\
\hline $2016-2017$ & 17 & 10.82 & 4 & 12.12 & 21 & 11.05 \\
\hline Total & $\mathbf{1 5 7}$ & $\mathbf{1 0 0}$ & $\mathbf{3 3}$ & $\mathbf{1 0 0}$ & $\mathbf{1 9 0}$ & $\mathbf{1 0 0}$ \\
\hline
\end{tabular}

ISSN: $2456-7620$ 
The table shows that for the past 8 years, KSU have already sent one hundred ninety (190) students in Israel as On-TheJob-Trainees which is $100 \%$ of the quota given to the University. There were more male OJTs with a total of 157 or $82.63 \%$ than the females with 33 or $17.37 \%$. It can be noted that on the first four years' partnership of KSU and Agro-studies program, only males participated in the said program however on the succeeding years, few female OJTs were qualified to participate. This implies that the work requires physical work where the males are more fit in the work than females.

Table 2. Distribution of OJTs in Terms of Coursel Academic Program

\begin{tabular}{|l|l|l|l|l|l|l|}
\hline \multirow{2}{*}{ Year } & \multicolumn{6}{|l|}{ Course Program } \\
\cline { 2 - 7 } & BS Agri. & BS AF & BS Forestry & $\begin{array}{l}\text { BS Ang. } \\
\text { Eng. }\end{array}$ & BAT & \\
\hline $2009-2010$ & 2 & 1 & 2 & 0 & 1 & $\mathbf{6}$ \\
\hline $2010-2011$ & 3 & 2 & 3 & 2 & 2 & $\mathbf{1 2}$ \\
\hline $2011-2012$ & 1 & 7 & 4 & 4 & 0 & $\mathbf{1 6}$ \\
\hline $2012-2013$ & 4 & 4 & 5 & 1 & 1 & $\mathbf{1 5}$ \\
\hline $2013-2014$ & 13 & 13 & 3 & 1 & 1 & $\mathbf{3 1}$ \\
\hline $2014-2015$ & 40 & 16 & 2 & 7 & 0 & $\mathbf{6 5}$ \\
\hline $2015-2016$ & 13 & 0 & 6 & 5 & 0 & $\mathbf{2 4}$ \\
\hline $2016-2017$ & 20 & 0 & 0 & 1 & 0 & $\mathbf{2 1}$ \\
\hline TOTAL & $\mathbf{9 6}$ & $\mathbf{4 3}$ & $\mathbf{2 5}$ & $\mathbf{2 1}$ & $\mathbf{5}$ & $\mathbf{1 9 0}$ \\
\hline
\end{tabular}

It can be seen from the table that BS Agriculture had the biggest number with 96 or $50.53 \%$ followed by BS Agro Forestry with 43 or $22.63 \%$. BS Forestry had 25 or $13.16 \%$ followed closely by BS Agricultural Engineering with 21 or 11.05\%. Bachelor in Agricultural Technology had 5 or 2.63 $\%$. This implies that agro-studies' give priority to the Bachelor of Science in Agriculture since Israel farms are more on Horticulture and livestock farming.
The table further shows that since 2014, Bachelor in Agriculture Technology have zero participation. This is because of the guidelines issued by CHED that only level 2 accredited program by the Accrediting Agency of Chartered Colleges and Universities of the Philippines (AACCUP)are allowed to participate in the said program. These are stipulated in CMO 22, s.2013.

Table 3. Presents the level of attainment of the objectives of the SIAP-OJT in Israel AgroStudies.

\begin{tabular}{|l|l|c|c|c|c|}
\hline I. & What is the level of attainment of the following objectives? & $\begin{array}{c}\text { Much } \\
\text { Attained } \\
\text { (MA) } \\
\mathbf{( 3 )}\end{array}$ & $\begin{array}{c}\text { Moderately } \\
\text { Attained } \\
\text { MoA } \\
\text { (2) }\end{array}$ & $\begin{array}{c}\text { Not } \\
\text { Attained } \\
\text { (A) }\end{array}$ & $\begin{array}{c}\text { Weighted } \\
\text { Mean } \\
\text { (WM) }\end{array}$ \\
\hline 1 & $\begin{array}{l}\text { The program Centre will hone the students' skills and practical } \\
\text { knowledge in different agricultural technologies and production } \\
\text { systems aimed at training them to be would-be entrepreneurs. }\end{array}$ & $\begin{array}{c}59 \\
(117)\end{array}$ & 36 & 0 & 2.62 \\
\hline 2 & $\begin{array}{l}\text { Student intern will perform required skills and techniques } \\
\text { necessary in the execution of operational procedures of the } \\
\text { assigned tasks in accordance with the existing work place, } \\
\text { health and safety standards. }\end{array}$ & 66 & 29 & 0 & 3.00 \\
$(198)$ & $(87)$ & $(0)$ & \\
\hline
\end{tabular}




\begin{tabular}{|l|l|c|c|c|c|}
\hline 3 & $\begin{array}{l}\text { The intern student will be exposed to the various modern } \\
\text { standards, methods and technologies practices by Agro-studies. }\end{array}$ & $\begin{array}{c}54 \\
(162)\end{array}$ & $\begin{array}{c}41 \\
(82)\end{array}$ & $\begin{array}{c}0 \\
(0)\end{array}$ & 2.57 \\
\hline 4 & $\begin{array}{l}\text { Intern students will develop skills in the application of theory to } \\
\text { practical work situation }\end{array}$ & $\begin{array}{c}51 \\
(153)\end{array}$ & $\begin{array}{c}31 \\
(62)\end{array}$ & $\begin{array}{c}13 \\
(13)\end{array}$ & 2.40 \\
\hline 5 & $\begin{array}{l}\text { Intern students will develop self-confidence, self-motivation and } \\
\text { positive attitude towards work }\end{array}$ & $\begin{array}{c}66 \\
(198)\end{array}$ & $\begin{array}{c}21 \\
(42)\end{array}$ & $\begin{array}{c}(8) \\
(8)\end{array}$ & 2.61 \\
\hline 6 & $\begin{array}{l}\text { Agro-studies will assign a tutor according to their field of } \\
\text { studies which includes lectures and meetings with } \\
\text { internationally renowned experts in various fields in } \\
\text { Agriculture. }\end{array}$ & $\begin{array}{c}69 \\
(207)\end{array}$ & $\begin{array}{c}(52) \\
(0)\end{array}$ & 2.73 \\
\hline & & TAWM & & $\mathbf{2 . 6 6}$ \\
\hline
\end{tabular}

As shown on the table, the total average weighted mean is 2.66 which is described as Much Attained. This implies that all the objectives of the On-the-job training of students as stipulated in the Memorandum of Understanding between KSU and the Israel Agro-studies were much attained.

Among the identified objectives, objective No. 2 "Student intern will perform required skills and techniques necessary in the execution of operational procedures of the assigned tasks in accordance with the existing work place, health and safety standards." got the highest mean of 3.0 described as much attained. This shows that the student interns who went to Israel had performed the required skills and techniques necessary in the execution of their tasks in accordance with the existing work place, health and safety standards.

The different farms where the trainees stayed strictly followed the existing policies thus student trainees where obliged to abide and perform their tasks in accordance with these policies.

Second on the rank is objective no. 6 with a mean of 2.73 which means "much attained". This implies that agroStudies indeed assigned tutors in all cooperating farms to guide student interns and to facilitate how they will go about their given work through lectures and meetings supplemented by educational field tours. The OJT Students were also given the opportunities to interact and acculturate themselves with other cultures. They learned to practice cultural adjustments through cultural accommodation and assimilation which is important in globalization.

Objectives 1 and 5 were both perceived as much attained with a weighted mean of 2.62 and 2.61 respectively. This implies that the interns learned much during their practical training and frontal studies by the 3 AgroStudies campuses. The training program provided the student interns with necessary technical exposure of real world farming problems and practices. The training program also allowed them to develop self-confidence, self-motivation and positive attitude towards work. The training program developed their personal skills and human relations.

The intern student will be exposed to the various modern standards, methods and technologies practices by Agro-studies and "Intern students will develop skills in the application of theory to practical work situation" were much attained too with a weighted mean of 2.57 and 2.40 respectively. This implies that the farms where the trainees were assigned used high technology machineries/equipment which gave the students the opportunity to manipulate such machineries/equipment. 
Table 4. Shows the factors affecting the level of attainment of the objectives

\begin{tabular}{|c|c|c|c|c|c|}
\hline II & $\begin{array}{l}\text { Factors affecting the level of attainment of the } \\
\text { objectives }\end{array}$ & $\begin{array}{c}\text { Most Affect } \\
\text { MA } \\
\text { (3) }\end{array}$ & $\begin{array}{c}\text { Moderately } \\
\text { Affect } \\
\text { MoA } \\
\text { (2) }\end{array}$ & $\begin{array}{c}\text { Not Affect } \\
\text { A } \\
\text { (1) }\end{array}$ & $\begin{array}{l}\text { Weighted } \\
\text { Mean }\end{array}$ \\
\hline 1 & Personality of the Supervisor & $\begin{array}{l}64 \\
(192)\end{array}$ & $\begin{array}{l}15 \\
(30)\end{array}$ & $\begin{array}{l}16 \\
(16)\end{array}$ & 2.51 \\
\hline 2 & Type of accommodation & $\begin{array}{l}8 \\
(24)\end{array}$ & $\begin{array}{l}52 \\
(104)\end{array}$ & $\begin{array}{l}(35 \\
(35)\end{array}$ & 1.72 \\
\hline 3 & Appropriate training of student intern & $\begin{array}{l}24 \\
(72)\end{array}$ & $\begin{array}{l}56 \\
(112)\end{array}$ & $\begin{array}{l}15 \\
(15)\end{array}$ & 2.09 \\
\hline 4 & Personality of student leaders & $\begin{array}{l}0 \\
(0)\end{array}$ & $\begin{array}{l}12 \\
(24)\end{array}$ & $\begin{array}{l}83 \\
(83)\end{array}$ & 1.13 \\
\hline 5 & Type of work given to students & $\begin{array}{l}25 \\
(75)\end{array}$ & $\begin{array}{l}66 \\
(132)\end{array}$ & $\begin{array}{l}4 \\
(4)\end{array}$ & 2.22 \\
\hline 6 & Location/site of the assigned farm & $\begin{array}{l}14 \\
(42)\end{array}$ & $\begin{array}{l}30 \\
(60)\end{array}$ & $\begin{array}{l}51 \\
(51)\end{array}$ & 1.61 \\
\hline 7 & Motivational approaches of supervisor & $\begin{array}{l}49 \\
(98)\end{array}$ & $\begin{array}{l}34 \\
(68)\end{array}$ & $\begin{array}{l}12 \\
(12)\end{array}$ & 1.87 \\
\hline 8 & Physical and mental health of the student intern & $\begin{array}{l}76 \\
(228)\end{array}$ & $\begin{array}{l}14 \\
(28)\end{array}$ & $\begin{array}{l}5 \\
(5)\end{array}$ & 2.75 \\
\hline 9 & Work environment/climate & $\begin{array}{l}40 \\
(120)\end{array}$ & $\begin{array}{l}52 \\
(104)\end{array}$ & $\begin{array}{l}3 \\
(3)\end{array}$ & 2.39 \\
\hline 10 & Policies, rules and regulations of the training & $\begin{array}{l}30 \\
(90)\end{array}$ & $\begin{array}{l}44 \\
(88)\end{array}$ & $\begin{array}{l}21 \\
(21)\end{array}$ & 2.09 \\
\hline \multicolumn{5}{|c|}{ TAWM } & 2.03 \\
\hline
\end{tabular}

As revealed on the table, the total average weighted mean of 2.03 was described as moderately affect. This generally means that the factors being cited moderately affected the attainment of the objectives.

The factor that got the highest mean of 2.75 which was described as much affect was on "Physical and mental health of the student intern". This implies that student interns experienced stress and anxiety on their new assigned work and new environment aside from being with other interns from other SUCs in the Philippines and other nationalities like Cambodia, Thailand and Uganda. Pressures from the supervisors and the work itself was also claimed as stressful.
People with high level of self-related Stress and anxiety are more likely affects mental and physical health of an individual. (https://www.mentalhealth.org.uk/a-toz/p/physical-health-and-mental-health)

Second highest indicator is on "Personality of the Supervisor" which has a weighted mean of 2.5 described as much affect. According to Zaide, "he stressed that every nation has its own culture that serves as its identity. One of it is the attitude of people that goes on with their culture". This indicates that the student interns had that feeling of uneasiness because they thought of their supervisors as strict but later it was the other way around. According to most of the interns, 
their supervisors were kind, approachable and considerate that made the interns do their work diligently.

Third highest indicator was on "work environment/climate" which has a weighted mean of 2.39 described as much affect. This implies that new workplace and new work experiences such as an air-conditioned workplace, acres of crop farms where they were assigned affected the attainment of the objectives. Some of the interns said they enjoy working in an air conditioned workplace and some also said that the climate was different from the Philippines however; they were able to adjust in time.

"Type of work given to student intern" got a weighted mean of 2.22 which is described as moderately affect. This implies that student interns that specializes in crop science and animal science who were assigned to Horticulture and livestock were comfortable given that they had the background in such work however, student interns who were not crop and animal science majors though their courses were Agriculture related, had to exert more effort to cope up with the given work which was on horticulture and livestock farming.

Factors "Appropriate training of student intern" and Policies, rules and regulations of training" was rated as moderately affect by both with a weighted mean of 2.09. This means that student interns perceived their experiences as applicable when they would be into farming and entrepreneurship in the future. Likewise, the policies, rules and regulations of the training were perceived by the interns as appropriate for the smooth operation of the work to be done. That means less percentage of spoilages in the production.

"Motivational approaches of supervisors was described as much affect with a weighted mean on 1.87. This implies that supervisors were approachable that boost the student interns to work diligently.

The "Type of accommodation" was described as moderately affect with a weighted mean of 1.72 . This means that the student interns were provided with a cozy and fully furnished boarding houses.

"Location/site of the assigned farm" got a weighted mean of 1.61 which is described as moderately affect. This implies that the distance between boarding house and farm was acceptable by the interns. Further, they were fetched from their boarding houses with a decent shuttle vans to ensure safety of the interns while travelling.

Of the enumerated factors, the indicator that got the lowest weighted mean of 1.13 which was described as not affect is under "personality of student intern". This means that the student interns were emotionally and socially prepared before going to Israel.

Table 5. Table 5 shows the identified problems encountered while undergoing the OJT in Israel, ranked accordingly.

\begin{tabular}{|l|l|}
\hline III & Problems encountered while undergoing the OJT in Israel \\
\hline 1 & Climate during winter \\
\hline 2 & Language barrier between supervisor and students (Some supervisors could hardly speak in English) \\
\hline 3 & $\begin{array}{l}\text { Field of specialization not related to given work (Animal Science majors are given work supposed } \\
\text { to be by Crop Science Majors) }\end{array}$ \\
\hline 4 & Very early fetching of students from quarters to work \\
\hline 5 & Sleepy in class because they work at night before schedules classes \\
\hline 6 & Inadequate equipment/tools in some farm \\
\hline 7 & Home sickness \\
\hline 8 & Some Animal Science major students were assigned to Horticulture farms \\
\hline 9 & Discrepancy in allowances received and the number of hours in some farms \\
\hline
\end{tabular}

Number one in the list of problems is on "climate during winter". Philippines has only two (2) season. We have only dry and wet seasons. Since they are not habituated to the winter season in Israel, they had a hard time adapting to the new atmosphere. Nevertheless, their work as interns went on normally. 
"Language barrier between supervisor and students" (Some supervisors could hardly speak in English) was claimed as a problem encountered too. With this kind of situation, communication between student and supervisor had a hard time understanding each other. As they claimed, some supervisors could hardly speak English which is supposed to be the "Lengua franca" of the people there. As a result, the interns as well as the supervisors add sign languages as they speak to be fully understood by both.

Another problem they have encountered during their internship in Israel was that their "Field of specialization was not related to given work such as animal Science majors assigned tohorticulture farmingwhich is for crop science majors". This implies that Israel farms were more on horticulture farming than livestock farming. As a result, some animal science majors were assigned to horticulture farming. This further supports the terms and conditions signed by the student that AgroStudies does not warrant the interns' choice will be available and the student hereby acknowledge that he may be positioned to a field of practice other than the one preferred by him, his specialization. (Agricultural Educational Terms and Conditions by AgroStudies)

"Very early fetching of students from quarters to work". This is another problem they have encountered. This means that farms were located away from their boarding houses/quarter so that students must be fetching very early in the morning so they could be in the farm on time. The interns considered it as a problem because they were not used to this kind of experience. However, the interns were able to adjust their body clock within a month.

"Sleepy in class" was claimed as a problem encountered. This indicates that some interns were given overtime work during night time so that when they go to class, they were sleepy.

"Home sickness" is another problem they have encountered. This is but normal especially that they are thousand miles away from their home. Nevertheless, interns found comfort by communicating with their love ones through the use of social media like video calling on messenger, face book and skype.

"Discrepancy in allowance received and the number of hours rendered in some farms". This implies that the agreed allowance in the Memorandum of Understanding was not followed. However, in the terms and conditions signed by the student intern, tuition fee, return air fare, tax and other fees and expenses will be deducted in their allowances.
The discrepancy is attributed to the farm's non peak season wherein interns have less working hours that upsets interns because it meant less allowance.

\section{CONCLUSION}

The findings suggest that the experiences of the KSU OJT in Israel gave them the necessary training specially in the skills and practical knowledge in different agricultural technologies and production systems aside from their exposure to the various modern standards, methods and technologies practiced by AgroStudies. Not to mention the self-confidence, self-motivation and positive attitude towards work that was developed in them during their OJT period.

It can be noted that there were problems encountered however the interns successfully dealt with those problems and continued their daily work activities normally.

The findings also indicate that Agrostudies prefer male OJT's than females because of the working condition in farms that requires physical strength.

In can also be concluded that work was on horticulture and livestock farming in which case, other agriculture related courses such as forestry and agricultural engineering were assigned to horticulture and livestock farming.

\section{RECOMMENDATIONS}

Based from the findings and conclusions, the following are recommended:

1. The terms and conditions set by Agro-Studies must be clearly understood by the intern.

2. PDOS must not be taken for granted. Parents/Guardians are obliged to attend.

3. There is a need to sustain and strengthen the partnership with IsraelAgro-Studies because it benefits the students and their families, particularly on educational and technological advancement, social, economic and cultural matters.

4. Hands on practicum in horticulture farming such as crop production and livestock such as poultry and the like must be enhanced in the Agriculture department of the university. 
5. A good internet connection for monitoring the interns progress and safety with the use of social media.

6. SIAP-OJT Israel coordinator if possible should come from the College of Agriculture so that the knowledge and skills learned at Agro-Studies could be applied through project proposals from the interns that will be implemented, monitored and evaluated by the Agriculture department.

7. The University Administration may opt to explore other Countries for deployment of OJT Students of other degree programs through the International Linkages office of the University.

\section{REFERENCES}

[1] http://www.AgroStudies.com

[2] https://www.mentalhealth.org.uk/a-to-z/p/physical-healthand-mental-health)

[3] Heather Huhman, contributor http://www.usnews.com/outside-voices-careers

[4] Douglas Chan, Article Contributor https://pcdreams.com.sg/importance-of-on-the-job-training/

[5] Susan Kihn, Article contributor, https://careermine.com

[6] Susan Heathfield, article contributor https://www.thebalancecareers.com

[7] Emerson V. Barcellano, The University's OJT Program in Israel, KSU. June 2016

[8] Revised KSU Policies and Guidelines for the OJTA and SIAP Manual, 2015. BOT Res \# 126 s. 2015.

[9] CHED CMO No. 22 s. 2013 